\title{
Structural Differentiation of Uronosyl Substitution Patterns in Acidic Heteroxylans by Electrospray Tandem Mass Spectrometry
}

\author{
Ana Reis, Paula Pinto, M. A. Coimbra, Dmitry V. Evtuguin, \\ Carlos P. Neto, A. J. Ferrer Correia, and M. Rosário M. Domingues \\ Department of Chemistry, University of Aveiro, Aveiro, Portugal
}

\begin{abstract}
The structures of two oligomers of acidic xylo-oligosaccharides (XOS) of the same molecular weight $(634 \mathrm{Da}), \mathrm{Xyl}_{2} \mathrm{MeGlcAHex}$ and $\mathrm{Xyl}_{2} \mathrm{GlcA}_{2}$ were differentiated by electrospray tandem mass spectrometry (ESI-MS/MS). These oligomers were present in a mixture of XOS obtained by acid hydrolysis of heteroxylans extracted from Eucalyptus globulus wood ( $\mathrm{Xyl}_{2} \mathrm{MeGl}_{\mathrm{HAHe}}$ ) and Olea europaea olive fruit $\left(\mathrm{Xyl}_{2} \mathrm{GlcA}_{2}\right)$. In the ESI-MS spectra of the XOS, ions at $\mathrm{m} / \mathrm{z} 657$ and 652 were observed and assigned to $[\mathrm{M}+\mathrm{Na}]^{+}$and $\left[\mathrm{M}+\mathrm{NH}_{4}\right]^{+}$, respectively. The ESI-MS/MS spectrum of $\left[\mathrm{M}+\mathrm{Na}^{+}\right.$ion of $\mathrm{Xyl}_{2} \mathrm{MeGl}$ AHex showed the loss of Hex residue from the reducing end followed by the loss of MeGlcA moiety. Simultaneously, the loss of a Xyl residue from either the reducing or the non-reducing ends was detected. On the other hand, the fragmentation of $\mathrm{Xyl}_{2} \mathrm{GlcA}_{2}$ occurs mainly by the loss of one and two GlcA residues or by the loss of the GlcAXyl moiety, due to the glycosidic bond cleavage between the two Xyl residues. Loss of one and two $\mathrm{CO}_{2}$ molecules was only observed for this oligomer, where the GlcA are in vicinal Xyl residues. The ESI-MS/MS spectra of $\left[\mathrm{M}+\mathrm{NH}_{4}\right]^{+}$of both oligomers showed the loss of $\mathrm{NH}_{3}$, resulting in the protonated molecule, where the presence of ions assigned as protonated molecules of aldobiuronic acid residues, [MeGlcA $-\mathrm{Xyl}+\mathrm{H}]^{+}$and [GlcA $-\mathrm{Xyl}$ $+\mathrm{H}^{+}$, are diagnostic ions of the presence of MeGlcA and GlcA moieties in XOS. Since these structures occur in small amounts in complex acidic XOS mixtures and are very difficult, if possible, to isolate, tandem mass spectrometry revealed to be a powerful tool for the characterization of these types of substitution patterns present in heteroxylans. (J Am Soc Mass Spectrom 2004, 15, 43-47) (C) 2004 American Society for Mass Spectrometry
\end{abstract}

$\mathrm{G}$ lucuronoxylans (GX) are heteropolysaccharides (hemicelluloses) present in cell walls of the most plants, fruits and vegetables [1,2]. These polysaccharides are comprised of a $\beta-(1 \rightarrow 4)$-linked xylan linear backbone ramified to different extents by $4-O-$ methyl-glucuronic (MeGlcA) and/or glucuronic (GlcA) acid residues, depending on their origin [1,2]. Some of the GX in plant tissues possess an additional backbone ramification with arabinose (Ara) residues to a lesser extent and of acetyl groups (Ac) at O-2 and O-3 positions of the xylopyranosyl residue [1,2]. The physiological function of GX in plant cells is still open to discussion [1-3]. It is certain that the physicochemical properties of cell walls are strongly affected by GX structural features (nature and frequency of the branching side chains, degree of the acetylation, molecular weight, etc.), which knowledge is crucial with regard to

Published online November 14, 2003

Address reprint requests to Dr. M. R. M Domingues, Department of Chemistry, University of Aveiro, 3810-193 Aveiro, Portugal. E-mail: mrd@dq.ua.pt the digestibility and processability behavior of plant/ fruit/vegetable tissues [1-3].

Commonly GX structures, as other hemicelluloses, are elucidated by the coupling of wet chemistry with NMR techniques [4,5]. However, these methods have several limitations, such as insufficiently high sensitivity towards important structural features of minor abundance (lower $2 \mathrm{~mol} \%$ ) and the poor information revealed on the primary structure of heteroxylans. Mass spectrometry (MS), particularly tandem mass spectrometry using either matrix assisted laser desorption ionization (MALDI) or electrospray (ESI), was shown to be useful for oligosaccharides structural characterization [6-8]. MS has been applied to the study of XOS, mainly using MALDI [9-12]. However, no tandem mass spectrometry studies were performed on the XOS ions produced by MALDI. ESI-MS was recently applied for the identification of underivatized olive pulp XOS, obtained by partial acid hydrolysis, both in positive [13, $14]$ and negative [14] modes, allowing the identification of neutral oligosaccharides of xylose $(\mathrm{Xyl}) \mathrm{Xyl}_{3-9}$, and acidic xylo-oligosaccharides substituted with MeGlcA 
(a)

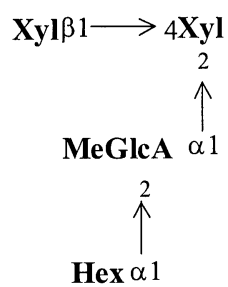

(b)

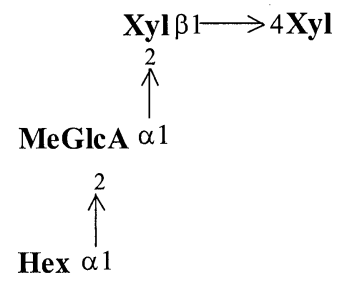

(c)

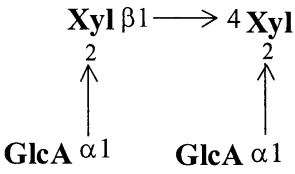

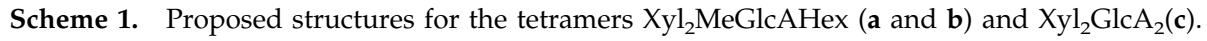

$\left(\mathrm{Xyl}_{2-11} \mathrm{MeGlcA}\right)$ or GlcA $\left(\mathrm{Xyl}_{3-5} \mathrm{GlcA}\right)[13,14]$. Tandem mass spectrometry analyses were performed on the observed ions allowing to confirm the presence of the acidic residue (MeGlcA and GlcA) and to propose a possible location along the XOS chain. During the study of olive pulp XOS by ESI-MS [13], one ion at $\mathrm{m} / \mathrm{z} 657$ corresponding to the $[\mathrm{M}+\mathrm{Na}]^{+}$ion was tentatively assigned to the tetramer $\mathrm{Xyl}_{2} \mathrm{GlcA}_{2}$, considering the previous methylation analysis and ${ }^{13} \mathrm{C}$ NMR spectroscopy studies [15]. Interestingly, an ion with the same $\mathrm{m} / \mathrm{z}$ value, $\mathrm{m} / \mathrm{z}$ at 657 , was observed during ESI-MS analysis of acidic XOS fraction obtained by partial hydrolysis of E. globulus GX (data not published). Taking into account the absence of GlcA moieties in the eucalypt GX and NMR structural investigations [16], this ion at $m / z 657$ was tentatively assigned to [M+ $\mathrm{Na}]^{+}$of tetramer $\mathrm{Xyl}_{2} \mathrm{MeGl}_{\mathrm{CAHex}}$ (Hex-hexose). Due to the low abundance of this tetramer in the fraction of acidic XOS (hexose side chains are very labile under acid hydrolysis) its clear identification by long-range proton correlation NMR technique (NOESY) was impossible. Thus, these tetramers from GX of olive pulp and of eucalyptus wood were analyzed by ESI-MS/MS. To our knowledge, fragmentation studies have never been performed on XOS containing two GlcA residues or even in xylo-oligosaccharides containing a Hex residue linked to the MeGlcA residue. Since both tetramers occur in complex mixtures and are difficult to isolate, the confirmation of these structures can only be achieved through tandem mass spectrometry.

In this study, the ESI-MS/MS spectra performed on the $[\mathrm{M}+\mathrm{Na}]^{+}$and $\left[\mathrm{M}+\mathrm{NH}_{4}\right]^{+}$ions of both tetramers, $\mathrm{Xyl}_{2} \mathrm{MeGlcAHex}$ from eucalypt wood, and $\mathrm{Xyl}_{2} \mathrm{GlcA}_{2}$ from olive pulp, are presented. Detailed fragmentation patterns related to these tetramers allowed for the first time unambiguous differentiation of these structural features in GX. Tandem mass spectrometry has been shown to be a valuable tool for the differentiation of uronosyl substitution patterns in acidic XOS of the same molecular mass obtained from partial acid of glucuronoxylans.

\section{Experimental}

Olive (Olea europaea L.) XOS isolation (by SEC) and characterization were described elsewhere [13]. The heteroxylan from Eucalyptus globulus L. wood was iso- lated from corresponding peracetic holocellulose by extraction with dimethylsulfoxide [16]. Wood XOS were obtained from heteroxylans sample $(30 \mathrm{mg})$ treated with trifluoroacetic acid, $50 \mathrm{mM}$, at $100{ }^{\circ} \mathrm{C}$ for $1 \mathrm{~h}$. The XOS were separated by preparative HPSEC (pump Knauer K-1001, Berlin, Germany) using a Shodex KS 2002 (Showa Denko K.K.) sugar column (20 mm $\times 300 \mathrm{~mm})$ at $30^{\circ} \mathrm{C}$ and ultra-pure water $(\mathrm{pH} 5.8$ adjusted with $\mathrm{H}_{2} \mathrm{SO}_{4}$ diluted solution) as eluent at a flow rate of $2.80 \mathrm{~mL} / \mathrm{min}$ and a detector RI (Knauer $\mathrm{K}-2401)$. The injected sample volume was $500 \mu \mathrm{L}$. The acidic XOS were eluted in one broad peak at elution time of ca. $12 \mathrm{~min}$, whereas neutral XOS revealed rather narrow peaks at elution times of $14 \mathrm{~min}$ (pentamers/ hexamers), $15 \mathrm{~min}$ (tetramers), $16.5 \mathrm{~min}$ (trimers), 17.5 min (dimers), and 19.5 min (monomers).

The ESI-MS and ESI-MS/MS were carried out on a Q-TOF2 instrument (Micromass, Manchester, UK). In MS and MS/MS experiments TOF resolution was set to approximately 10,000. Data acquisition was carried out with a MassLynx 4 data system. Oligosaccharides were dissolved in $200 \mu \mathrm{L}$ of methanol:water:formic acid (50:49:1, vol/vol/vol) and introduced into the electrospray source at a flow rate of $10 \mu \mathrm{L} / \mathrm{min}$. The cone voltage was set at $35 \mathrm{~V}$ and capillary voltage at $3 \mathrm{kV}$. Source temperature was at $80^{\circ} \mathrm{C}$ and desolvation temperature at $150{ }^{\circ} \mathrm{C}$. Tandem mass spectra were obtained using Ar as the collision gas. The collision energy used for sodium adducts was set between $40-55 \mathrm{~V}$, while for ammonium adducts it was set between 18-22 V. Ammonium adducts of wood sample were formed by addition of a diluted solution of $10 \mu \mathrm{L}$ of ammonium acetate $(1 \mathrm{mg} / \mathrm{mL})$ to $0.5 \mathrm{~mL}$ of the solution of oligosaccharides.

\section{Results and Discussion}

The structures proposed for $\mathrm{Xyl}_{2} \mathrm{MeGlcAHex}$ and $\mathrm{Xyl}_{2} \mathrm{GlcA}_{2}$, obtained from Eucalyptus globulus wood and olive, respectively, are shown in Scheme 1. Two tetramers can be expected from $\mathrm{Xyl}_{2} \mathrm{MeGlcAHex}$ (a and $\mathbf{b}$ ), and only one structure is possible for $\mathrm{Xyl}_{2} \mathrm{GlcA}_{2}$ (c). Fragmentation studies were performed in order to confirm the proposed structures. Confirmation of types of linkages was not attempted in this study.

The ESI-MS spectra of both XOS samples showed the $[\mathrm{M}+\mathrm{Na}]^{+}$and $\left[\mathrm{M}+\mathrm{NH}_{4}\right]^{+}$ions, at $m / z 657$ and 652, 

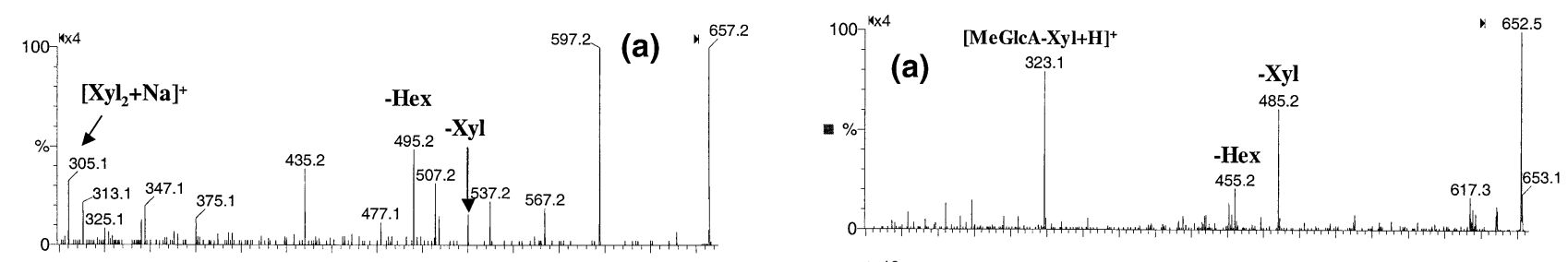

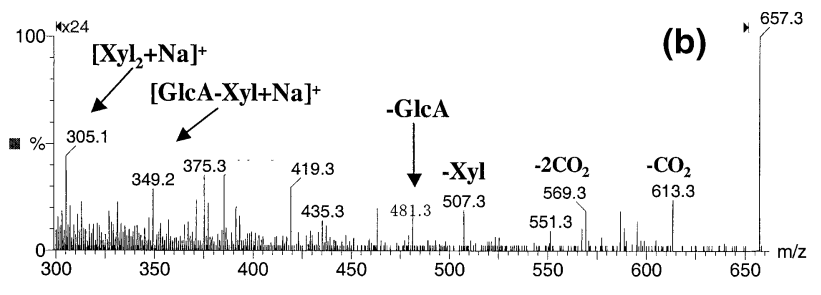

Figure 1. ESI-MS/MS spectra of $[\mathrm{M}+\mathrm{Na}]^{+}$ions at $m / z 657$ of (a) $\mathrm{Xyl}_{2} \mathrm{MeGlcAHex}$ and (b) $\mathrm{Xyl}_{2} \mathrm{GlcA}_{2}$.

respectively. The formation of the $\left[\mathrm{M}+\mathrm{NH}_{4}\right]^{+}$adduct of $\mathrm{Xyl}_{2} \mathrm{MeGlcAHex}$ was induced, since it was not observed in the initial XOS ESI-MS spectrum. In order to confirm the proposed structures, the fragmentation pattern of both $[\mathrm{M}+\mathrm{Na}]^{+}$and $\left[\mathrm{M}+\mathrm{NH}_{4}\right]^{+}$ions, at $\mathrm{m} / \mathrm{z}$ 657 and 652 , respectively, were studied.

\section{Fragmentation of $[\mathrm{M}+\mathrm{Na}]^{+}$Ions at $\mathrm{m} / \mathrm{z} 657$}

The ESI-MS/MS spectra obtained for the $[\mathrm{M}+\mathrm{Na}]^{+}$ ions of $\mathrm{Xyl}_{2} \mathrm{MeGlcAHex}$ and $\mathrm{Xyl}_{2} \mathrm{GlcA}_{2}$ at $\mathrm{m} / \mathrm{z} 657$ are shown in Figure 1. Comparing both spectra it is possible to observe different fragmentation patterns that allowed distinguishing both tetramers.

In the MS/MS spectrum of $\mathrm{Xyl}_{2} \mathrm{MeGlcAHex}_{\text {(Figure }}$ 1a), it is possible to observe an ion at $m / z 495$ attributed to the loss of $162 \mathrm{Da}$, indicative of the presence of a Hex. On the other hand, the ions at $\mathrm{m} / \mathrm{z} 597\left(\right.$ loss of $\mathrm{C}_{2} \mathrm{H}_{4} \mathrm{O}_{2}$ ), 567 (loss of $\mathrm{C}_{3} \mathrm{H}_{6} \mathrm{O}_{3}$ ), and 537 (loss of $\mathrm{C}_{4} \mathrm{H}_{10} \mathrm{O}_{4}$ ), are due to cross-ring cleavages of the Hex that are characteristic of Hex fragmentation [17, 18]. Furthermore, the ion at $\mathrm{m} / \mathrm{z} 185$ (data not shown), corresponding to $[\mathrm{M}+\mathrm{Na}]^{+}$ of the Hex, also corroborates its presence in this molecule. Loss of Xyl occurring from both the reducing and the non-reducing end is observed for the tetramers $\mathrm{Xyl}_{2} \mathrm{MeGlcAHex}$, corresponding to the ions at $\mathrm{m} / \mathrm{z} 507$

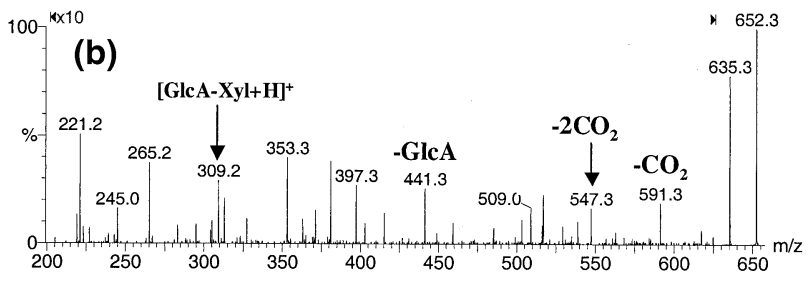

Figure 2. ESI-MS/MS spectra of $\left[\mathrm{M}+\mathrm{NH}_{4}\right]^{+}$ions at $\mathrm{m} / \mathrm{z} 652$ of (a) $\mathrm{Xyl}_{2} \mathrm{MeGlcAHex}$ and (b) $\mathrm{Xyl}_{2} \mathrm{GlcA}_{2}$.

(loss of $150 \mathrm{Da}$ ) and at $\mathrm{m} / \mathrm{z} 525$ (loss of $132 \mathrm{Da}$ ), respectively. This may be explained taking into account the linkage of MeGlcA either to the Xyl in the reducing, or in the non-reducing terminal (Scheme 2, Structures a and $\mathbf{b}$ ). The ion at $\mathrm{m} / z$ 305, attributed to $\left[\mathrm{Xyl}_{2}+\mathrm{Na}\right]^{+}$, can be formed by successive elimination of Hex and MeGlcA, or due to cleavage between MeGlcA - Xyl with loss of Hex - MeGlcA. The absence of a fragment ion formed by loss of MeGlcA (190 Da) from the precursor ion, which was found to be characteristic of $\mathrm{Xyl}_{\mathrm{n}} \mathrm{MeGlcA}[13,14]$, supports the presence of MeGlcA between $\mathrm{Xyl}$ and Hex, as shown in Scheme 2 . The ion at $m / z 375$, identified as [Hex $\left.-\mathrm{MeGlcA}-\mathrm{H}_{2} \mathrm{O}+\mathrm{Na}\right]^{+}$, also confirmed the proposed structure.

The MS/MS spectra of the $\left[\mathrm{M}+\mathrm{Na}^{+}\right.$ion of $\mathrm{Xyl}_{2} \mathrm{GlcA}_{2}$ (Figure $1 \mathrm{~b}$ ) did not show any fragment resulting from the loss of Hex or MeGlcA, which excluded the presence of these residues in this molecule. In fact, it was possible to detect the ion at $\mathrm{m} / \mathrm{z} 481$ and the ion at $\mathrm{m} / \mathrm{z} 305$ (identified as $\left[\mathrm{Xyl}_{2}+\mathrm{Na}\right]^{+}$) due to loss of one and two GlcA, confirming the presence of two GlcA in the molecule $[13,14]$. The glycosidic cleavage between the two $\mathrm{Xyl}$ led to the ions at $m / z 349$ $[\mathrm{GlcA}-\mathrm{Xyl}+\mathrm{Na}]^{+}$and 331 [GlcA $-\mathrm{Xyl}-\mathrm{H}_{2} \mathrm{O}+$ $\mathrm{Na}]^{+}$. The loss of GlcA can occur in combination with loss of $\mathrm{CO}_{2}$, occurring either as B-type fragmentation (a)

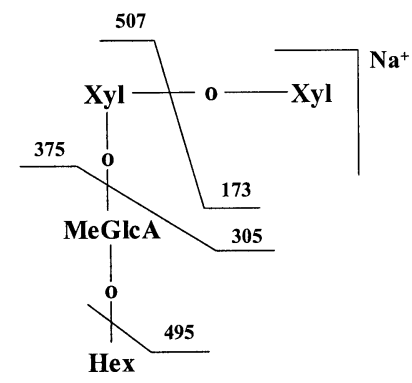

(b)

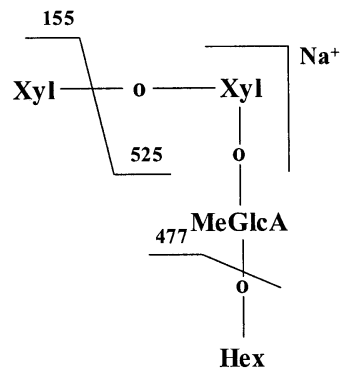

(c)

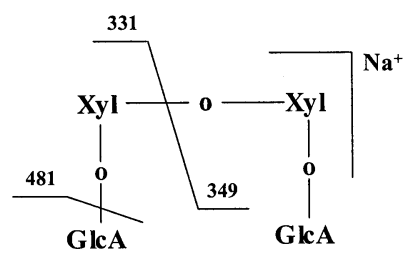

Scheme 2. Proposed fragmentation pathways for the $[\mathrm{M}+\mathrm{Na}]^{+}$of $\mathrm{Xyl}_{2} \mathrm{MeGlcAHex}(\mathbf{a}$ and $\mathbf{b})$ and $\mathrm{Xyl}_{2} \mathrm{GlcA}_{2}(\mathbf{c})$. 
(a)

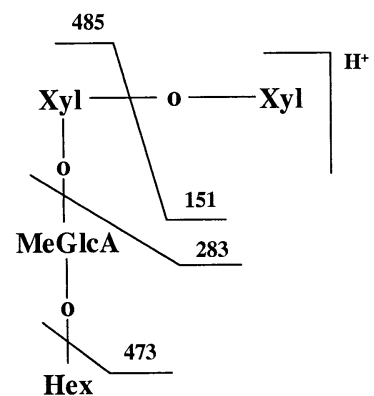

(b)

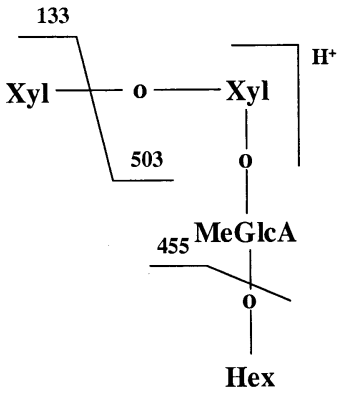

(c)

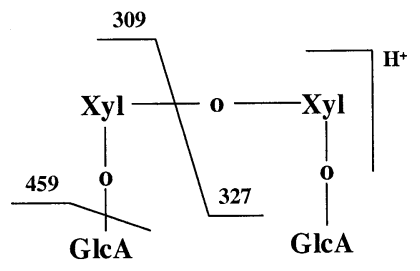

Scheme 3. Proposed fragmentation pathways for the $\left[\mathrm{M}+\mathrm{NH}_{4}\right]^{+}$of $\mathrm{Xyl}_{2} \mathrm{MeGl}_{\mathrm{C}} \mathrm{AHex}(\mathbf{a}$ and $\mathbf{b})$ and $\mathrm{Xyl}_{2} \mathrm{GlcA}_{2}$ (c).

$(\mathrm{m} / \mathrm{z} 419)$, or as Y-type $(\mathrm{m} / \mathrm{z} 437)$, according to the nomenclature proposed by Domon and Costello [19]. Interestingly, the ions at $\mathrm{m} / \mathrm{z} 613$ and 569 were found to be due to the loss of one and two $\mathrm{CO}_{2}$ groups from [M $+\mathrm{Na}]^{+}$. These fragmentations were not observed in the

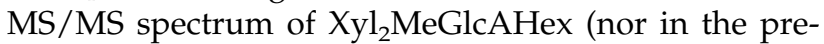
viously studied $\mathrm{Xyl}_{\mathrm{n}} \mathrm{GlcA}$ or $\left.\mathrm{Xyl}_{\mathrm{n}} \mathrm{MeGlcA}[13,14]\right)$ and are probably due to decarboxilation of acidic residues in vicinal Xyl. In fact, loss of $\mathrm{CO}_{2}$ is a characteristic of the spectra of dicarboxylic acids [20]. The fragment observed at $\mathrm{m} / \mathrm{z} 507$, attributed to combined loss of water and loss of $\mathrm{Xyl}$, is only expected to occur taking into account a first loss of water involving both carboxylic groups, forming an anhydride intramolecular ring, that allows further loss of the $\mathrm{Xyl}$ residue. Vicinal dicarboxylic acids are known to undergo loss of $\mathrm{H}_{2} \mathrm{O}$, forming an anhydride [20]. The fragment at $\mathrm{m} / \mathrm{z} 525$ attributed to loss of Xyl $(-150 \mathrm{Da})$ is explained by rearrangement and internal residue loss [21,22], probably facilitated by the presence of the GlcA in vicinal Xyl.

\section{Fragmentation of $\left[\mathrm{M}+\mathrm{NH}_{4}\right]^{+}$ions at $\mathrm{m} / z 652$}

ESI-MS/MS spectra obtained for the $\left[\mathrm{M}+\mathrm{NH}_{4}\right]^{+}$ions of the $\mathrm{Xyl}_{2} \mathrm{MeGlcAHex}$ and $\mathrm{Xyl}_{2} \mathrm{GlcA}_{2}$ at $\mathrm{m} / \mathrm{z} 652$ are shown in Figure 2. As observed before for other XOS $[13,14]$, the MS/MS spectra of the $\left[\mathrm{M}+\mathrm{NH}_{4}\right]^{+}$exhibited a different fragmentation pattern from the $[\mathrm{M}+$ $\mathrm{Na}]^{+}$. In both $\left[\mathrm{M}+\mathrm{NH}_{4}\right]^{+}$spectra it is possible to observe a first loss of $\mathrm{NH}_{3}$, leading to the formation of the protonated molecule $[\mathrm{M}+\mathrm{H}]^{+}$at $m / z 635$.

Considering the fragmentation of $\mathrm{Xyl}_{2} \mathrm{MeGlcAHex}$ (Figure 2a) it is possible to observe the successive elimination of Xyl (as B-type, loss of $150 \mathrm{Da}$ ), leading to the ion at $\mathrm{m} / \mathrm{z} 485$, and of Hex (-162 Da), forming the ion at $\mathrm{m} / \mathrm{z} 323$ (Scheme $\mathbf{3 a}$ and $\mathbf{b}$ ). This ion corresponded to the protonated aldobiuronic residue, $[\mathrm{MeGlcA}-\mathrm{Xyl}$ $+\mathrm{H}]^{+}$, that is a characteristic of the $\left[\mathrm{M}+\mathrm{NH}_{4}\right]^{+}$ MS/MS spectra of the acidic XOS substituted with MeGlcA [13, 14]. This fragment can also be formed by successive loss of hexose (as B-type, $180 \mathrm{Da}$ ) from the $[\mathrm{M}+\mathrm{H}]^{+}$leading to the fragment at $\mathrm{m} / \mathrm{z} 455$, followed by loss of Xyl from the non-reducing end (132 Da). No loss of MeGlcA is observed from the protonated molecule.

The MS/MS spectrum of $\mathrm{Xyl}_{2} \mathrm{GlcA}_{2}$ (Figure 2b) showed the fragment at $\mathrm{m} / \mathrm{z} 441$ (loss of $194 \mathrm{Da}$ ) evidencing the presence of GlcA. Successive loss of the two GlcA residues from the precursor ion occurs with formation of the $\left[\mathrm{Xyl}_{2}+\mathrm{H}\right]^{+}$ion as B-type $(\mathrm{m} / \mathrm{z} 265)$ and as Y-type $(\mathrm{m} / \mathrm{z} 283)$. Cleavage between the two $\mathrm{Xyl}$ residues leads to the ion at $m / z 309$, [GlcA $-\mathrm{Xyl}-\mathrm{H}_{2} \mathrm{O}$ $+\mathrm{H}]^{+}$, through B-type fragmentation and to the ion at $m / z$ 327, [GlcA - Xyl $+\mathrm{H}^{+}$, due to Y-type fragmentation (Scheme 3c). In this spectrum, loss of one and two $\mathrm{CO}_{2}$ from $[\mathrm{M}+\mathrm{H}]^{+}$leading to the ions at $m / z 591$ and 547 , respectively, is also detected, similarly to what was observed for the MS/MS spectrum of $[\mathrm{M}+\mathrm{Na}]^{+}$. The fragment at $m / z 525$, attributed to the combined loss of $\mathrm{H}_{2} \mathrm{O}$ and $\mathrm{Xyl}(150 \mathrm{Da})$, can only be explained taking into account the fragmentation pathway proposed for the $[\mathrm{M}+\mathrm{Na}]^{+}$. These results confirm the occurrence of two GlcA acid residues located in vicinal Xyl residues.

\section{Conclusions}

Different fragmentation patterns were observed by tandem mass spectrometry of acidic tetramer xylo-oligosaccharides containing the same molecular mass. This allowed an accurate identification of uronosyl substitutions in complex mixtures of XOS, not possible by the usual methodologies in carbohydrate structural analysis. Data obtained by ESI-MS/MS provide new insights into the structure of GX of different origin, contributing to our understanding of their physiological role in plant/fruit cell walls.

\section{Acknowledgments}

The authors gratefully acknowledge FCT funding provided for the Research Unit Química Orgânica, Produtos Naturais e AgroAlimentares, Project (POCTI/1999/CTM/34159) and a Ph.D. grant to PP (SFRH/BD/1096/2000). 


\section{References}

1. Selvendran, R. R. Developments in the Chemistry and Biochemistry of Pectic and Hemicellulosic Polymers. J. Cell Sci. Suppl. 1985, 2, 51-88.

2. Shimizu, K. Wood and Cellulosic Chemistry; Hon, D.N.-S.; Shiraishi, N., Eds.; Marcel Dekker: New York, 1991; 177-214.

3. Jung, G. H.; Buxton, D. R.; Hatfield, R. D.; Ralph, J. Forage Cell Wall Structure and Digestibility; ASA-CSSA-SSSA: Madison, WI, 1993, pp. 183-396.

4. Chaplin, M. F.; Kennedy, J. F. Carbohydrate Analysis. A Practical Approach; IRL Press at Oxford University Press: New York, 1994, pp. 73-112.

5. Teleman, A.; Lundqvist, J.; Tjerneld, F.; Stalbrand, H.; Dahlman, O. Characterization of Acetylated 4-O-Methylglucuronoxylan from Aspen Employing ${ }^{1} \mathrm{H}$ and ${ }^{13} \mathrm{C}$ NMR Spectroscopy. Carbohydr. Res. 2000, 329, 807-815.

6. Harvey, D. J. Matrix-Assisted Laser Desorption/Ionization Mass Spectrometry of Carbohydrates. Mass Spectrom. Rev. 1999, 18, 349-451.

7. Harvey, D. J. Collision-Induced Fragmentation of Underivatized N-Linked Carbohydrates Ionized by Electrospray. J. Mass Spectrom. 2000, 35, 1178-1190.

8. Fernández, L. E. M.; Obel, N.; Scheller, H. V.; Roepstorff, P. Characterization of Plant Oligosaccharides by Matrix-Assisted Laser Desorption/Ionization and Electrospray Mass Spectrometry. J. Mass Spectrom. 2003, 38, 427-437.

9. Teleman, A.; Tenkanen, M.; Jacobs, A.; Dahlman, O. Characterization of O-acetyl-(4-O-Methylglucurono)-Xylan Isolated from Birch and Beech. Carbohydr. Res. 2002, 337, 373-377.

10. Jacobs, A.; Larsson, P.; Dahlman, O. Distribution of Uronic Acids in Xylans from Various Species of Soft- and Hardwood as Determined by MALDI Mass Spectrometry. Biomacromol. 2001, 2, 979-990.

11. Vierhuis, E.; Schols, H. A.; Beldman, G.; Voragen, A. G. J. Structural Characterization of Xyloglucan and Xylans Present in Olive Fruit (Olea europaea cv koroneiki). Carbohydr. Polym. 2001, 44, 51-62.

12. Reis, A.; Domingues, M. R. M.; Ferrer-Correia, A. J.; Coimbra, M. A. Structural Characterization by MALDI-MS of Olive Xylo-Oligosaccharides Obtained by Partial Acid Hydrolysis. Carbohydr. Polym. 2003, 53, 101-107.
13. Reis, A.; Coimbra, M. A.; Domingues, P.; Ferrer-Correia, A. J.; Domingues, M. R. M. Structural Characterization of Underivatized Olive Pulp Xylo-Oligosaccharides by Mass Spectrometry Using Matrix Assisted Laser Desorption/Ionization and Electrospray Ionization. Rapid Commun. Mass Spectrom. 2002, 16, 2124-2132.

14. Reis, A.; Domingues, M. R. M.; Domingues, P.; Ferrer-Correia, A. J.; Coimbra, M. A. Positive and Negative Electrospray Ionization Tandem Mass Spectrometry as a Tool for Structural Characterization of Acid Released Oligosaccharides from Olive Pulp Glucuronoxylans. Carbohydr. Res. 2003, 338, 14971505.

15. Coimbra, M. A; Waldron , K. W.; Selvendran, R. R. Isolation and Characterization of Cell Wall Polymers from Olive Pulp. (Olea europaea L). Carbohydr. Res. 1994, 252, 245-262.

16. Evtuguin, D.; Tomás, J. L.; Silva, A. M. S.; Neto, C. P. Characterization of an Acetylated Heteroxylan from Eucalyptus globulus Labill. Carbohydr. Res. 2003, 338, 597-604.

17. Zhou, Z.; Ogden, S.; Leary, J. Linkage Position Determination in Oligosaccharides: MS/MS Study of Lithium-Cationized Carbohydrates. J. Org. Chem. 1990, 55, 5444-5446.

18. Spengler, B.; Dolce, J. W.; Cotter, R. J. Infrared Laser Ddesorption Mass Spectrometry of Oligosaccharides: Fragmentation Mechanism and Isomer Analysis. Anal. Chem. 1990, 62, 17311733.

19. Domon, B.; Costello, C. E. A Systematic Nomenclature for Carbohydrate Fragmentantion in FAB-MS/MS Spectra of Glycoconjugates. Glycoconj. J. 1988, 5, 397-409.

20. McLafferty, F. W.; Turecek, F. Interpretation of Mass Spectra; University Science Books: Mill Valley, 1993, pp 258-259.

21. Kovácik, V.; Hirsch, J.; Kovác, P.; Heerma, W.; Thomas-Oates, J.; Haverkamp, J. Oligosaccharide Characterization Using Collision-Induced Dissociation Fast Atom Bombardment Mass Spectrometry: Evidence for Internal Residue Loss. J. Mass Spectrom. 1995, 30, 949-958.

22. Warrack, B. M.; Hail, M. E.; Triolo, A.; Animati, F.; Seraglia, R.; Traldi, P. Observation of Internal Monosaccharide Losses in the Collisionally Activated Dissociation Mass Spectra of Anthracycline Aminodisaccharides. J. Am. Soc. Mass Spectrom. $1998,9,710-715$. 